\title{
MECHANOSYNTHESIS OF MMC CUC DOPED WITH TI FOR APPLICATION OF PANTOGRAPH CONTACT STRIP (PCS)
}

\section{PEMBUATAN METAL MATRIK KOMPOSIT CUC YANG DIDOPING DENGAN TI UNTUK APLIKASI PANTOGRAPH CONTACT STRIP (PCS)}

\author{
Andhika Abdan Rahmanullah', Pawawoi', Djoko Hadi Prajitno ${ }^{1,2}$ \\ ${ }^{1}$ Metallurgy Engineering, Faculty of Manufacture Engineering - UNJANI \\ ${ }^{2}$ Center for Nuclear Science and Technology Application \\ e-mail : dhika.1897@gmail.com
}

\begin{abstract}
This research was conducted to determine the effect of the addition of Titanium (Ti) and the sintering temperature variation on $\mathrm{MMC} \mathrm{CuC}$ alloys as reinforcing elements. The process of this research uses powder metallurgical method with an alloying technique in Mechanical Alloying using a Planetary Ball Mill (PBM) machine with a speed of $600 \mathrm{rpm}$ for 2 hours, the ratio of powder to the ball mill is 10:1. The compacting process is carried out using dies $11 \mathrm{~mm}$ in diameter and compacting pressure of $90 \mathrm{Kg} / \mathrm{cm}^{2}$. The sintering process is carried out three times, with variations in sintering of $800^{\circ} \mathrm{C}, 900^{\circ} \mathrm{C}$, and $1000^{\circ} \mathrm{C}$ with sintering time for 1 hour in the tube furnace in the argon gas vacuum environment. The number of samples used in this study amounted to 9 samples with variations in alloy and temperature sintering, consist of $\mathrm{MMC} \mathrm{CuC}$ alloy with addition of $\mathrm{Ti} 0 \%, 0.5 \%$, $1.5 \%\left(\mathrm{~T}=800{ }^{\circ} \mathrm{C}\right), \mathrm{MMC} \mathrm{CuC}$ with addition of $\mathrm{Ti} \% \%, 0.5 \%, 1.5 \%\left(\mathrm{~T}=900{ }^{\circ} \mathrm{C}\right)$, and MMC CuC with addition of $\mathrm{Ti} 0 \%, 0.5 \%, 1.5 \%\left(\mathrm{~T}=1000{ }^{\circ} \mathrm{C}\right)$. The tests included Vickers hardness testing, metallography testing, XRD testing, and SEM-EDS testing. The addition of Ti elements and varying sintering temperature had an effect on the hardness value of MMC CuC material with the highest hardness value in samples with $1.5 \% \mathrm{Ti}$ alloy $(800 \mathrm{oC})$ which is $87.25 \mathrm{HV}$, and the lowest porosity value is $2.491 \%$ in the sample of $1.5 \% \mathrm{Ti}\left(1000^{\circ} \mathrm{C}\right)$.
\end{abstract}

Keywords : MMC CuC; Mechanical Alloying; Titanium; Pantograph Contact Strip

\begin{abstract}
Abstrak
Penelitian ini dilakukan untuk menentukan pengaruh penambahan titanium (Ti) sebagai penguat dan variasi temperatur sintering MMC paduan CuC alloys. Proses penelitian menggunakan serbuk dengan teknik pemaduan mekanik menggunakan mesin Planetary Ball Mill (PBM) dengan kecepatan 600 rpm selama 2 Ratio antara bola grinding dan serbuk 10:1. Proses kompaksi dilakukan menggunakan cetakan dengan diameter $11 \mathrm{~mm}$ dan tekanan kompasi sebesar $90 \mathrm{Kg} / \mathrm{cm}^{2}$. Proses sintering dilakukan dengan variasi sintering of $800^{\circ} \mathrm{C}, 900^{\circ} \mathrm{C}$, dan $1000^{\circ} \mathrm{C}$ dengan waktu sintering selama 1 jam dalam tungku tabung dengan atmosfer lingkungan gas argon. Jumlah sampel dalam penelitian ada 9 dengan variasi komposisi paduan dan temperatur sintering, Sampel paduan MMC CuC terdiri dari paduan dengan penambahan Ti 0\%, 0,5\%, 1,5\% dan temperatur sintering $800^{\circ} \mathrm{C}, 900^{\circ} \mathrm{C}$ dan $1000^{\circ} \mathrm{C}$. Pengujian sampel hasil sintering meliputi Vickers microhardness, metallography, XRD, dan SEM-EDS. Penambahan unsur Ti pada paduan CuC dan variasi temperatur sintering mempengaruhi kekerasan paduan dan porositas paduan CuC-Ti. Harga kekerasan tertinggi terjadi pada paduan CuC-Ti dengan konsentrasi Ti 1,5\% temperatur sinter $800^{\circ} \mathrm{C}$ yaitu 87,25 HV, sedangkan porositas terendah yaitu 2,491\% pada sampel CuC dengan konsentrasi $1,5 \%$ temperatur sinter $1000^{\circ} \mathrm{C}$.
\end{abstract}

Kata kunci : MMC CuC; Pemaduan mekanik; Titanium; Pantograph Contact Strip Received: 29 February 2020, revised: 20 July 2020, accepted: 14 August 2020 


\section{INTRODUCTION}

In recent years, Electric Railways have developed rapidly due to the timeliness, ease and low environmental pollution in many countries throughout the world ${ }^{1}$. In China, the operating speed of the Electric Train system has reached more than $380 \mathrm{~km} / \mathrm{h}$, and the driving force has reached $10,000 \mathrm{~kW}^{2}$. In Indonesia, the Electric Train (KRL) currently has 80 stations and has 6 lines. In 2017 the number of KRL passengers reached 316 million users. The average speed of a KRL reaches $40 \mathrm{~km} / \mathrm{h}(25 \mathrm{mph})$ with a top speed reaching $70 \mathrm{~km} / \mathrm{h}(43 \mathrm{mph})$ and has a route as far as $235 \mathrm{~km}$ (146 mi) in Indonesia ${ }^{3}$.

In the electric train construction, there is a component called pantograph/pantograph contact strip with the location on the top of the electric train and contact with the cable power line. Pantograph contact strip has an essential role in the electric train operating system. Pantograph contact strip (PCS) functions as an electrical conductor which is the primary power source on the KRL so it can move ${ }^{1)}$. The characteristics of existing PCS are a critical basis for the schematic design and parameter selection of new contact lines. PCS must have certain basic features, which conform to the specified application. PCS characteristics have a significant impact on the quality of PCS operations and the overhead contact line system. Perfect design ensures suitable PCS operating performance on various contact lines ${ }^{4)}$.

Ensuring excellent contact between PCS and the catenary system has always been a goal for many researchers. However, contact performance is still far from satisfying at the moment, because PCS and the catenary system must experience a shock load caused by several factors, such as wear/friction, arc abrasion, and environmental erosion, and so on. This evolutionary process of PCS requires more comprehensive research ${ }^{5}$.

There are many types of PCS materials, but only carbon composite metals are used, both domestically and abroad. Copper material is advantageous when combined with metals for PCS material. Pure carbon and carbon added to metals for PCS materials significantly increase wear resistance due to excellent lubrication properties ${ }^{2}$. Therefore, to meet the requirements for making pantograph contact strips (PCS) on KRL, we can use materials made from carbon and copper by addition from other elements. In this study focuses on studying the effect of addition Ti gave on the PCS characteristics produced, among them the effect of variations in composition and sintering temperature on $\mathrm{MMC} \mathrm{CuC}$ material.

\section{MATERIALS AND METHODS}

The design of the research experiment to be carried out, as shown in Figure 1. The first stage is mixing the raw materials of $\mathrm{MMC} \mathrm{CuC}$ and $\mathrm{Ti}$, which varies in composition $0 \% \mathrm{Ti}$, $0.5 \% \mathrm{Ti}$, and $1.5 \% \mathrm{Ti}$. Then the CuC-Ti alloys are compacted with a pressure of $90 \mathrm{~kg} / \mathrm{cm}^{2}$. The results of compacting are then sintered at varying temperatures, $800^{\circ} \mathrm{C}, 900^{\circ} \mathrm{C}$ and $1000^{\circ} \mathrm{C}$

The design of the powder composition to be made is shown in Table 1. The powder composition used was calculated based on weight per cent and for each sample with different Ti composition variations. The naming of the sample shows numbers and letters. The numbers indicate the addition of Ti elements in per cent $(0 ; 0.5 ; 1.5)$, while the letters after the numbers indicate differences in sintering temperatures, namely $\mathrm{A}\left(800^{\circ} \mathrm{C}\right)$; $\mathrm{B}\left(900^{\circ} \mathrm{C}\right)$; and $C\left(1000^{\circ} \mathrm{C}\right)$. The nine samples were compacted with a pressure of $90 \mathrm{~kg} / \mathrm{cm}^{2}$.

Table 1.

Materials Balance Used in Research

\begin{tabular}{ccccc}
\hline \multirow{2}{*}{ Samples } & \multirow{2}{*}{$\begin{array}{c}\text { Temperature } \\
\text { Sintering }\left({ }^{\circ} \mathrm{C}\right)\end{array}$} & \multicolumn{3}{c}{ Weight \% } \\
\cline { 3 - 5 } & 800 & $\mathrm{Cu}$ & $\mathrm{C}$ & $\mathrm{Ti}$ \\
\hline $0 \mathrm{~A}$ & & & & \\
$0 \mathrm{~B}$ & 900 & 99.4 & 0.6 & 0 \\
$0 \mathrm{C}$ & 1,000 & & & \\
$0.5 \mathrm{~A}$ & 800 & & & \\
$0.5 \mathrm{~B}$ & 900 & 98.9 & 0.6 & 0.5 \\
$0.5 \mathrm{C}$ & 1,000 & & & \\
$1.5 \mathrm{~A}$ & 800 & & & \\
$1.5 \mathrm{~B}$ & 900 & 97.9 & 0.6 & 1.5 \\
$1.5 \mathrm{C}$ & 1,000 & & & \\
\hline
\end{tabular}

MMC CuC-Ti alloy samples were characterized by hardness, XRD, SEM, and metallographic testing. Hardness testing using Vickers with a load of $50 \mathrm{~kg}$ and a magnification of $100 \mu \mathrm{m}$. XRD (X-Ray Diffraction) testing aims to analyze the composition of the phases and compounds contained in the sample6). The SEM-EDS (Scanning Electron Microscopy - Energy Dispersive Spectrometer) test aims to determine the surface morphology of the specimens and analyze the elements formed in the material7).

SEM-EDS testing uses the SU3500 type HITACHI instruments. Metallographic testing was carried out with an optical microscope with a magnification of 50,100 and 200 to determine the microstructure formed. All characterization results are compiled and processed in graphical form, which correlates process parameters with characteristics of microstructures, and composition of elements. 


\section{RESULT AND DISCUSSION}

Research data can be obtained from the processed characterization results consisting of values and graphs. The characterization or testing process carried out on samples is Vickers hardness testing, Metallographic and Porosity testing, SEM-EDS testing, and XRD testing.

\section{Hardness Testing (Vickers)}

The results of the analysis of Vickers hardness testing of MMC CuC-Ti alloy samples are shown in Table 2.

Table 2.

Value Hardness Vickers

\begin{tabular}{ccccc}
\hline \multirow{2}{*}{ Samples } & \multicolumn{3}{c}{ Hardness (HVN) } & \multirow{2}{*}{$\begin{array}{c}\text { Average } \\
\text { (HVN) }\end{array}$} \\
\cline { 2 - 4 } & $\mathrm{I}$ & $\mathrm{II}$ & $\mathrm{III}$ & \\
\hline OA & 41.35 & 30.26 & 38.45 & 36.69 \\
0.5A & 52.00 & 63.63 & 61.29 & 58.97 \\
1.5A & 86.43 & 96.15 & 79.16 & 87.25 \\
0B & 27.52 & 29.28 & 28.28 & 28.36 \\
0.5B & 62.77 & 44.70 & 43.02 & 50.16 \\
1.5B & 50.46 & 59.96 & 52.28 & 54.23 \\
0C & 27.53 & 28.43 & 28.58 & 28.18 \\
0.5C & 39.67 & 34.57 & 39.88 & 38.04 \\
1.5C & 48.43 & 50.46 & 43.00 & 47.30 \\
\hline
\end{tabular}

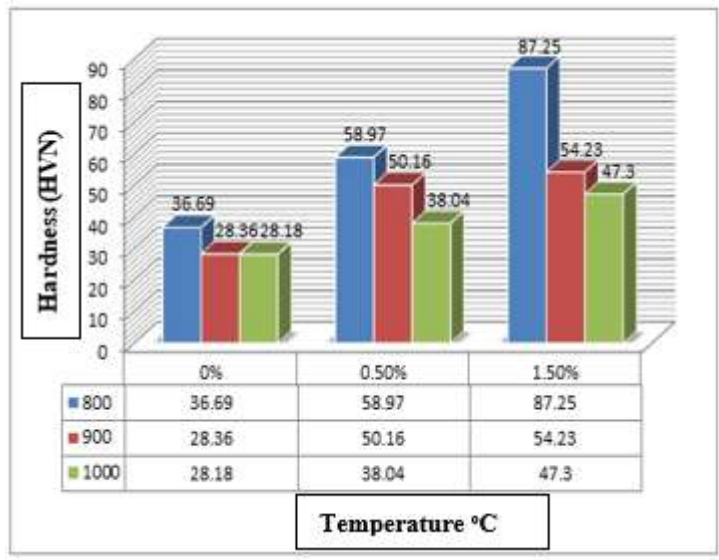

Figure 1.

The Average Hardness Testing Result

The data shows that the higher $\mathrm{Ti}$ addition to the mixture of MMC $\mathrm{CuC}$, the mechanical properties will be more robust. Strengthening of the dispersion occurs in powder metallurgical processes, where the compacting process followed by the sintering process is carried out in the mixing of hard powders and functional matrix powders. The hard particle will oppose the movement of dislocation. Overcoming dislocation occurs and dislocation ${ }^{8)}$ which lead to an increase in the strength of mechanical properties.

The CuC alloys, which are sinter at the temperature of $900^{\circ} \mathrm{C}$ and $1000^{\circ} \mathrm{C}$ have a lower hardness value compared with $800^{\circ} \mathrm{C}$. This occurred because the sintering process at high temperature occurs thermally and requires a diffusion process and resulting coarsening $\mathrm{Cu}$ become large grain ${ }^{9}$.

\section{Metallography Testing}

Metallographic testing was carried out on MMC CuC-Ti alloy samples from the sintering process with temperatures of $800^{\circ} \mathrm{C}, 900^{\circ} \mathrm{C}$ and $1000^{\circ} \mathrm{C}$. Metallographic testing is carried out to examine the microstructure formed on the $\mathrm{CuC}$ alloys.

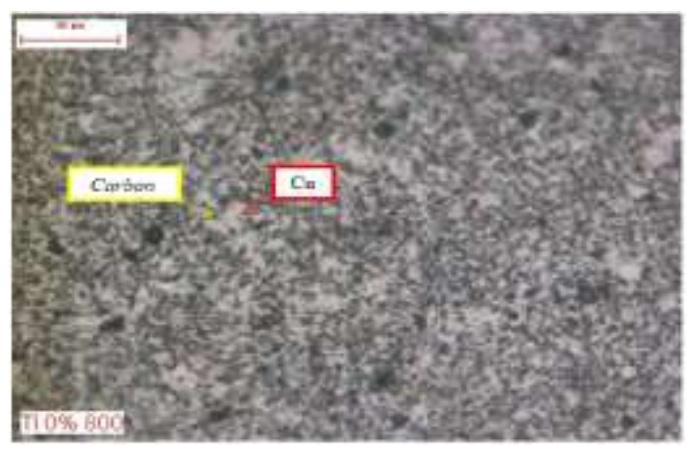

Figure 2.

Microstructure of the Specimen $\mathrm{Ti} 0 \%, 800^{\circ} \mathrm{C}$

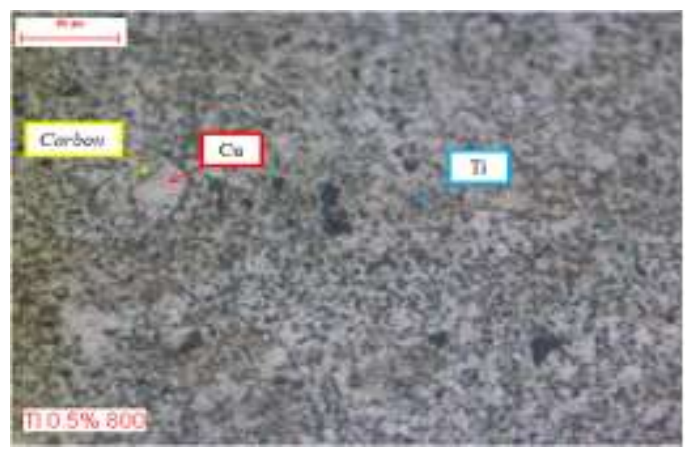

Figure 3.

Microstructure of the Specimen Ti $0.5 \%, 800^{\circ} \mathrm{C}$

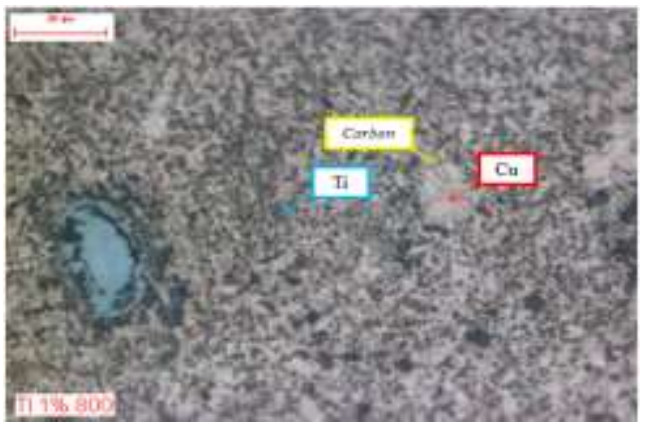

Figure 4.

Microstructure of the Specimen Ti $1.5 \%, 800^{\circ} \mathrm{C}$ 


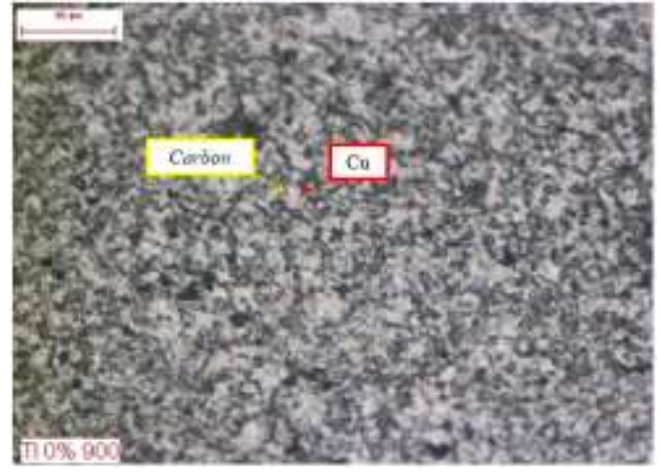

Figure 5.

Microstructure of the Specimen Ti $0 \%, 900^{\circ} \mathrm{C}$

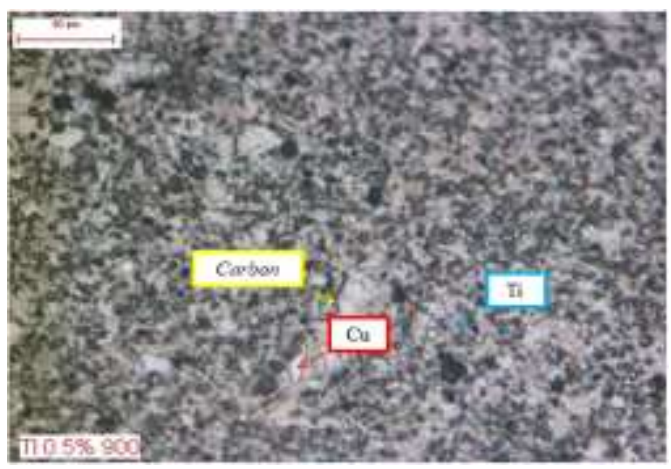

Figure 6.

Microstructure of the Specimen Ti $0.5 \%, 900^{\circ} \mathrm{C}$

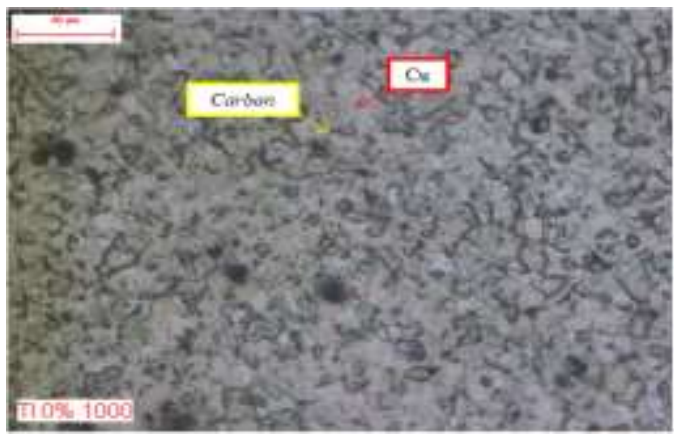

Figure 7.

Microstructure of the Specimen $\mathrm{Ti} 1.5 \%, 900^{\circ} \mathrm{C}$

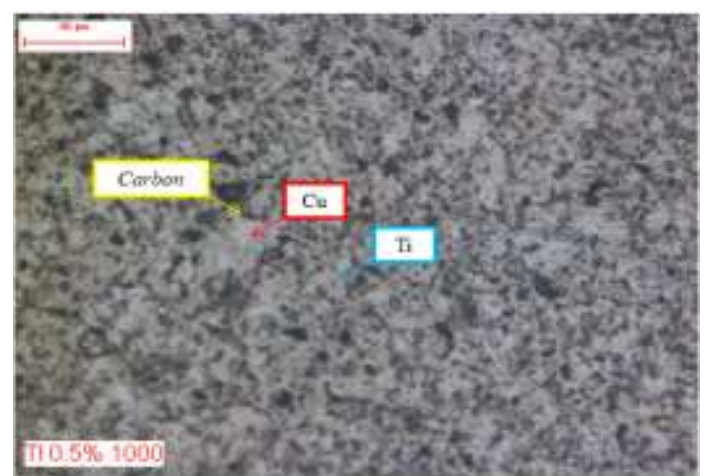

Figure 8.

Microstructure of the Specimen Ti $0 \%, 1000^{\circ} \mathrm{C}$

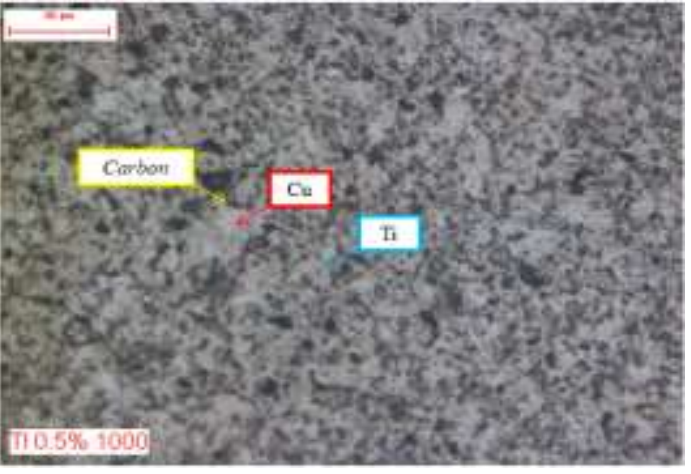

Figure 9.

Microstructure of the specimen Ti $0.5 \%, 1000^{\circ} \mathrm{C}$

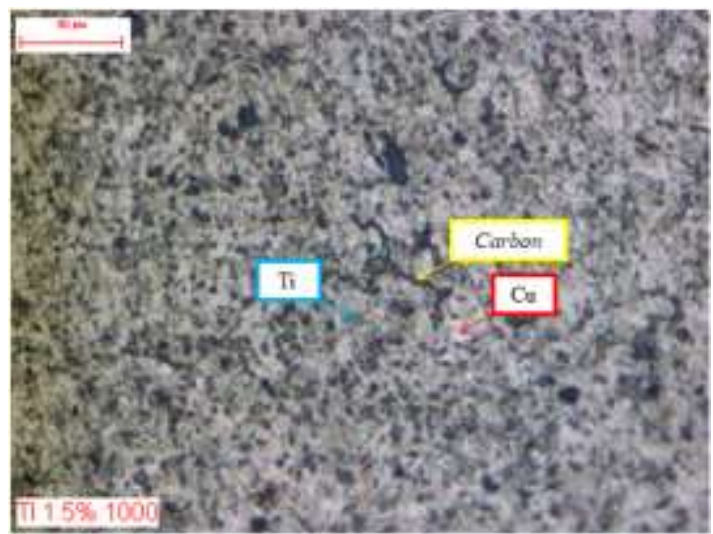

Figure 10.

Microstructure of the Specimen Ti $1.5 \%, 1000^{\circ} \mathrm{C}$

A number of the images above are the result of metallographic testing using an optical microscope with 200 magnification. After doing a qualitative analysis on the sample, it can identify the phases that appear, items with a bright colour $(\mathrm{Cu})$, black with a position on the grain boundary (Carbon) ${ }^{10}$, and grains with a grey colour $(\mathrm{Ti})^{11)}$. From the above data, it can also be seen that there are several microstructures with large grains. This is caused by an increase in temperature, which will affect the mechanical properties of the material. This event is following the sound of Hall-petch law, the larger the diameter of the grain the material hardness will decrease ${ }^{8)}$. Hall-petch's law can be proven by conducting quantitative analysis of microstructure.

\section{Grain Size Measurement}

The grain size measurement is conducted so that the grain size owned by each microstructure of each sample can be measured. The grain size then is related to the hardness testing result conducted on each specimen. The measurement process of this item uses two methods, namely the Heyn method and the Jeffries method, which refers to the ASTM E112 standard ${ }^{12}$. 
Table 3.

Value Average Grain Size Measurement

\begin{tabular}{|c|c|c|c|c|}
\hline \multirow{2}{*}{ No. } & \multirow{2}{*}{$\% \mathrm{Ti}$} & \multirow{2}{*}{$\begin{array}{c}\text { Temperature } \\
\text { Sintering } \\
\left({ }^{\circ} \mathrm{C}\right)\end{array}$} & \multicolumn{2}{|c|}{$\begin{array}{c}\text { Grain Size } \\
\text { Average }(\mu \mathrm{m})\end{array}$} \\
\hline & & & $\begin{array}{c}\text { Method } \\
\text { Heyn }\end{array}$ & $\begin{array}{l}\text { Method } \\
\text { Jeffries }\end{array}$ \\
\hline 1 & $0 \%$ & & 2.89 & 10.22 \\
\hline 2 & $0.5 \%$ & 800 & 2.39 & 9.66 \\
\hline 3 & $1.5 \%$ & & 2.00 & 9.28 \\
\hline 4 & $0 \%$ & & 3.07 & 10.30 \\
\hline 5 & $0.5 \%$ & 900 & 2.64 & 9.84 \\
\hline 6 & $1.5 \%$ & & 2.50 & 9.69 \\
\hline 7 & $0 \%$ & & 3.25 & 11.58 \\
\hline 8 & $0.5 \%$ & 1,000 & 3.03 & 9.95 \\
\hline 9 & $1.5 \%$ & & 2.81 & 9.60 \\
\hline
\end{tabular}

The measurement of the grain size of the microstructure of each sample shows that the average grain size will get bigger as the sintering temperature increases. The ideal sintering temperature is at $813^{\circ} \mathrm{C}$. If the given temperature has exceeded the ideal sintering temperature will result, in not only melting the surface of the grain but almost completely, especially at temperatures of $1,000^{\circ} \mathrm{C}$ which results in over sintering and grain enlargement [13]. Based on the results of the calculation of average grain size with the Heyn method, the largest average grain size is $3.25 \mu \mathrm{m}$ in the $\mathrm{Ti}$ sample of $0 \%\left(1,000^{\circ} \mathrm{C}\right)$ and the smallest average size of the meat is $2.00 \mu \mathrm{m}$ in the $\mathrm{Ti}$ specimen of $1.5 \%\left(800^{\circ} \mathrm{C}\right)$. Likewise, with the results of the Jeffries method which is directly proportional to the Heyn even though the nominal yields are different.

\section{Porosity Measurement}

Table 4.

Data Sample Porosity Measurement

\begin{tabular}{cccc}
\hline No. & Composition & $\begin{array}{c}\text { Temperature } \\
\text { Sintering } \\
\left({ }^{\circ} \mathrm{C}\right)\end{array}$ & $\begin{array}{c}\text { Porosity } \\
(\%)\end{array}$ \\
\hline 1 & & 800 & 10.279 \\
2 & CuC+Ti 0\% & 900 & 6.265 \\
3 & & 1,000 & 3.393 \\
4 & & 800 & 7.591 \\
5 & CuC+Ti 0.5\% & 900 & 4.626 \\
6 & & 1,000 & 3.022 \\
7 & & 800 & 5.589 \\
8 & CuC+Ti 1.5\% & 900 & 4.035 \\
9 & & 1,000 & 2.491 \\
\hline
\end{tabular}

Porosity data obtained from the observation of microstructure with a magnification of 200 and supported by image $\mathrm{J}$ software that aims to facilitate the porosity calculation process in the sample. The results shown are in the form of red areas indicating grain and black is porosity.

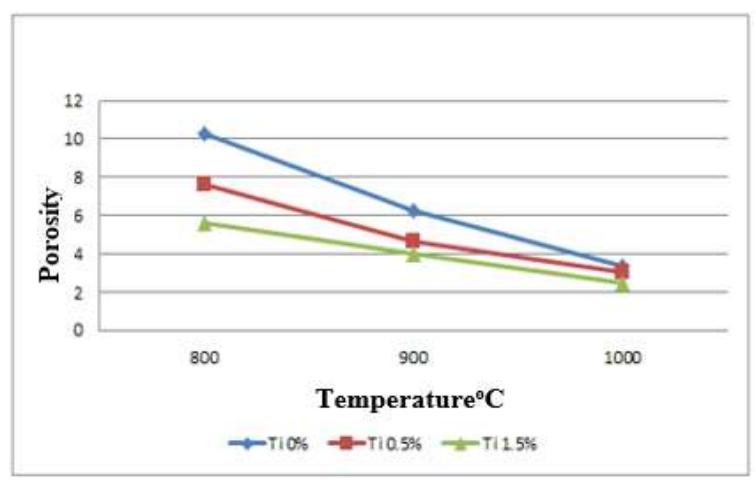

Figure 11.

Effect of Ti Concentration on the Porosity of $\mathrm{CuC}$

Based on the results of porosity testing using Image-J software on a microstructure with a magnification of 200 shown in Table 4 and Figure 11, porosity decreases with increasing sintering temperature. Increasing the temperature becomes greater causing an enlargement of the necking area on each powder particle which will cover the cavities between the powder particles, and the binding of the powder particles so that the percentage (\%) porosity will decrease ${ }^{14)}$. The lowest porosity value is owned by a temperature of $1000^{\circ} \mathrm{C}$, with $\mathrm{Ti} 1.5 \%$ of 2.491 . In comparison, the highest porosity \% value is at a temperature of $800^{\circ} \mathrm{C}$ with $\mathrm{Ti} 0 \%$ of $10.279 \%$.

\section{XRD Testing (X-Ray Diffraction)}

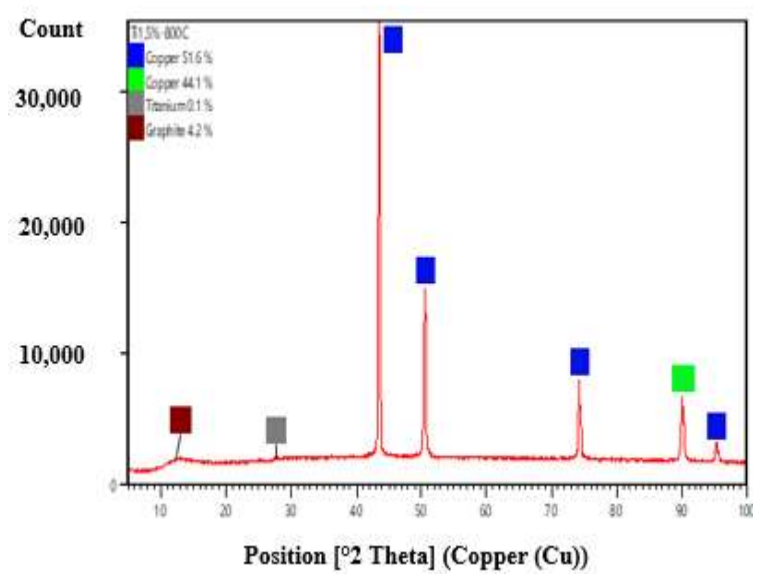

Figure 12.

XRD Specimen of Ti $1.5 \%, 800^{\circ} \mathrm{C}$ 
Table 5.

XRD Specimen of $\mathrm{Ti} 1.5 \%, 800^{\circ} \mathrm{C}$

\begin{tabular}{cccccc}
\hline No & Symbol & $\begin{array}{c}\text { Position } \\
\text { [2 Theta] } \\
\text { (Cu) }\end{array}$ & $\mathrm{Cu}$ & $\mathrm{Ti}$ & Graphite \\
\hline 1 & & 43.508 & $\checkmark$ & & \\
2 & $\square$ & 50.607 & $\checkmark$ & & \\
3 & $\square$ & 74.312 & $\checkmark$ & & \\
4 & & 90.089 & $\checkmark$ & & \\
5 & & 95.313 & $\checkmark$ & & \\
6 & & 27.643 & & $\checkmark$ & \\
7 & $\square$ & 12.218 & & & $\checkmark$ \\
\hline
\end{tabular}

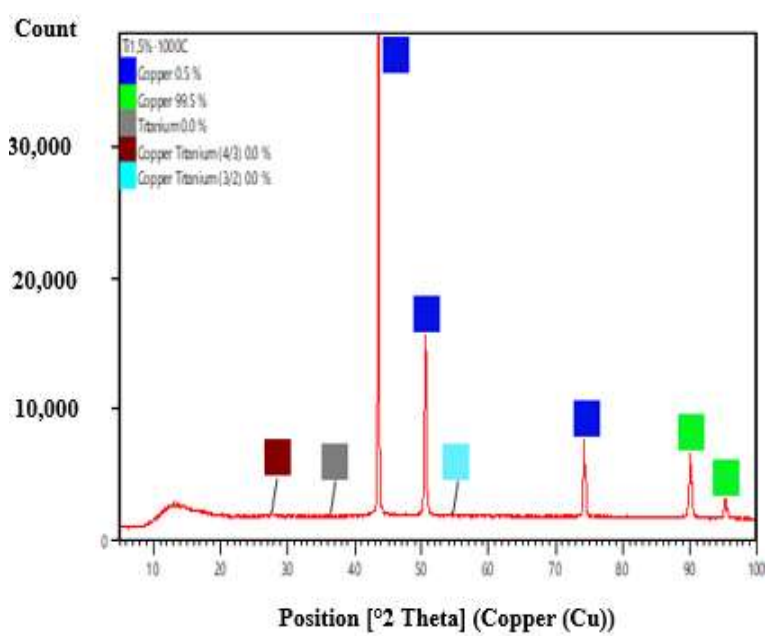

Figure 13.

XRD of $\mathrm{Ti} 1.5 \%, 1,000^{\circ} \mathrm{C}$

Table 6.

XRD of $\mathrm{Ti} 1.5 \%, 1,000^{\circ} \mathrm{C}$

\begin{tabular}{cccccc}
\hline No & Symbol & $\begin{array}{c}\text { Position } \\
\text { [2 Theta] } \\
\text { (Cu) }\end{array}$ & $\mathrm{Cu}$ & $\mathrm{Ti}$ & $\mathrm{Cu} / \mathrm{Ti}$ \\
\hline 1 & 43.550 & $\checkmark$ & & \\
2 & & 50.646 & $\checkmark$ & & \\
3 & & 54.523 & & $\checkmark$ \\
4 & & 74.331 & $\checkmark$ & & \\
5 & & 90.100 & $\checkmark$ & & \\
6 & & 95.134 & $\checkmark$ & & \\
7 & & 27.670 & & & $\checkmark$ \\
8 & & 36.334 & & $\checkmark$ & \\
\hline
\end{tabular}

X-Ray Diffraction (XRD) testing was carried out on 2 samples, namely samples using sintering temperatures of $800^{\circ} \mathrm{C}$ with $1.5 \% \mathrm{Ti}$ composition, and samples using sintering temperatures of $1000^{\circ} \mathrm{C}$ with $1.5 \% \mathrm{Ti}$ compositions. The XRD test results are shown in Fig. 13 - 14 and Table 5 -6.

XRD testing was carried out on two samples that had been sintered, namely the samples $1.5 \mathrm{~A}$ and $1.5 \mathrm{C}$. The $\mathrm{XRD}$ results show the highest peak obtained in sample $1.5 \mathrm{~A}$ at position 95.313 , while the $1.5 \mathrm{C}$ sample with the highest peak at position 95.134 with Cu each at the highest peak.

\section{Data SEM-EDS Testing}

SEM is an electron microscope that is designed to investigate the surface of solid objects directly, which has a magnification of 10 - 3000000x, depth of field $4-0.4 \mathrm{~mm}$ and a resolution of $1-10 \mathrm{~nm}^{15}$.

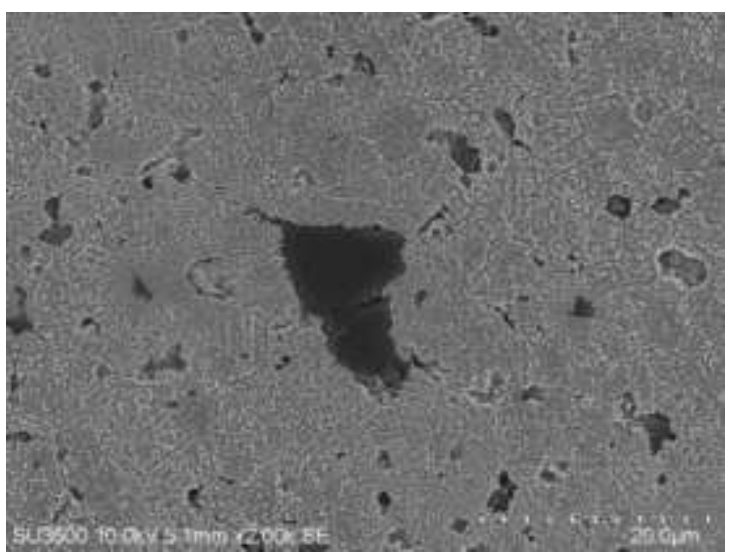

Figure 14

SEM Specimen of $\mathrm{Ti} 1.5 \%, 800^{\circ} \mathrm{C}$

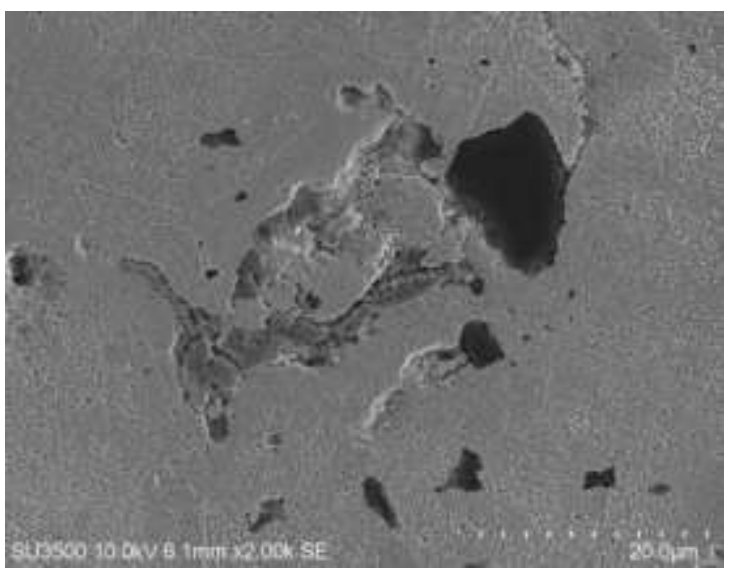

Figure 15

SEM Specimen Ti $1.5 \%, 1,000^{\circ} \mathrm{C}$ 


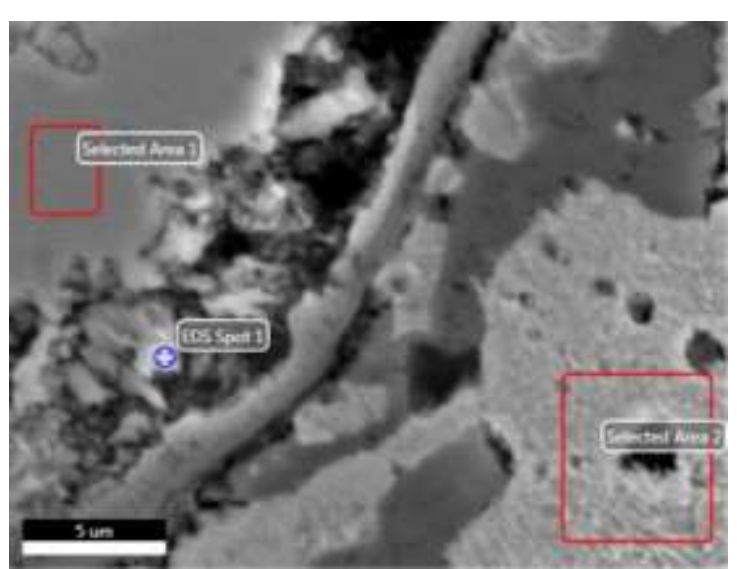

Figure 16.

EDS Specimen of Ti $1.5 \%, 800^{\circ} \mathrm{C}$

Table 7.

Mapping EDS Specimen of Ti $1.5 \%, 800^{\circ} \mathrm{C}$

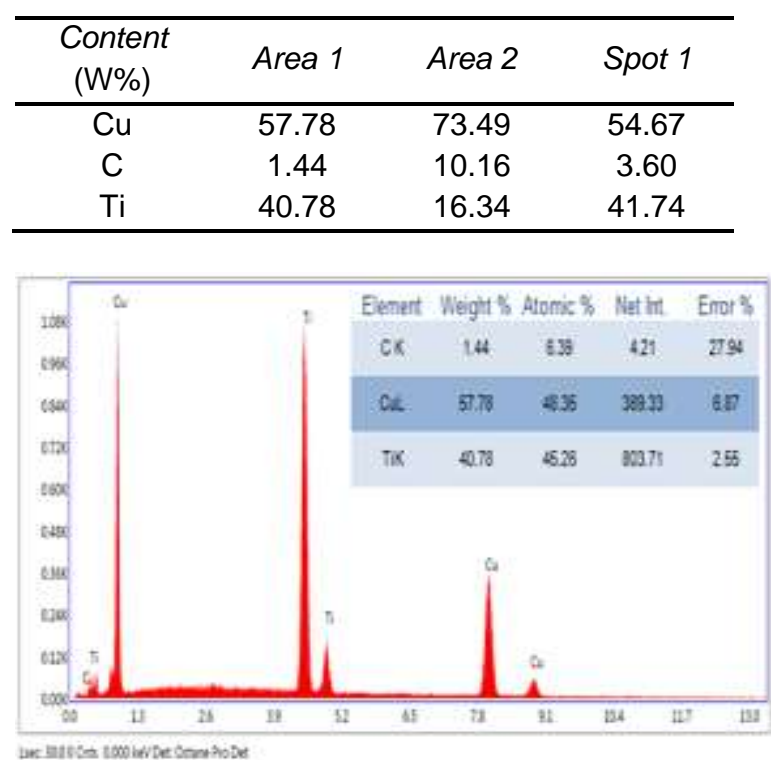

Figure 17.

Result EDS Area 1

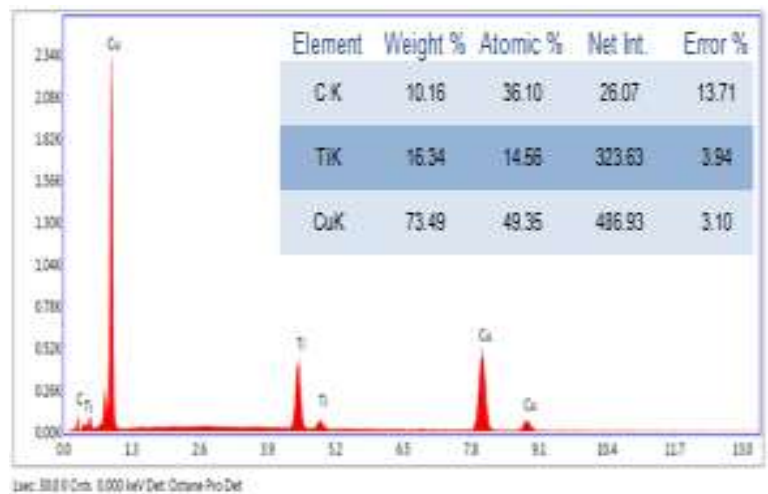

Figure 18

Result EDS Area 2

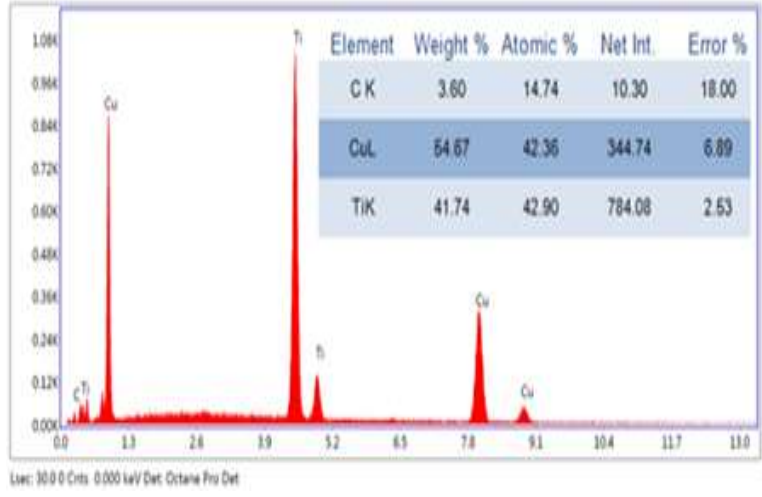

Figure 19.

Result EDS Spot 1

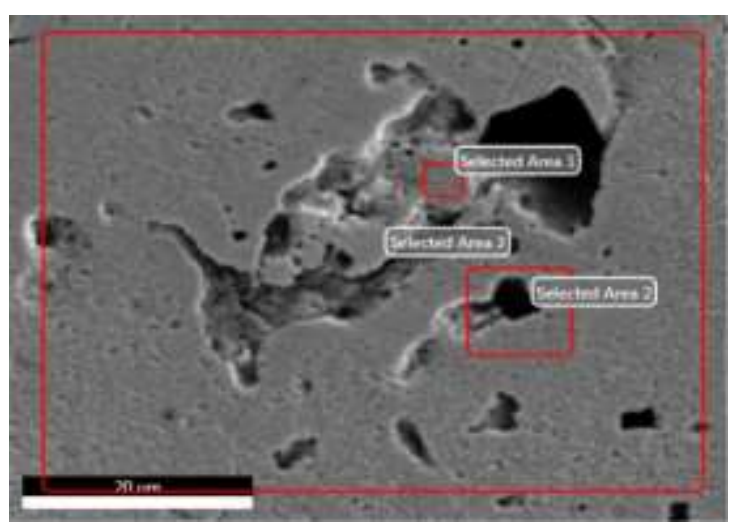

Figure 20

EDS Specimen of $\mathrm{Ti} 1.5 \%, 1,000^{\circ} \mathrm{C}$

Table 8.

Mapping EDS $\left(\mathrm{Ti} 1.5 \%, 1,000^{\circ} \mathrm{C}\right)$

\begin{tabular}{cccc}
\hline $\begin{array}{c}\text { Content } \\
(\mathrm{W} \%)\end{array}$ & Area 1 & Area 2 & Area 3 \\
\hline $\mathrm{Cu}$ & 96.92 & 77.81 & 85.02 \\
$\mathrm{C}$ & 2.79 & 21.86 & 13.54 \\
$\mathrm{Ti}$ & 0.29 & 0.33 & 1.44 \\
\hline
\end{tabular}

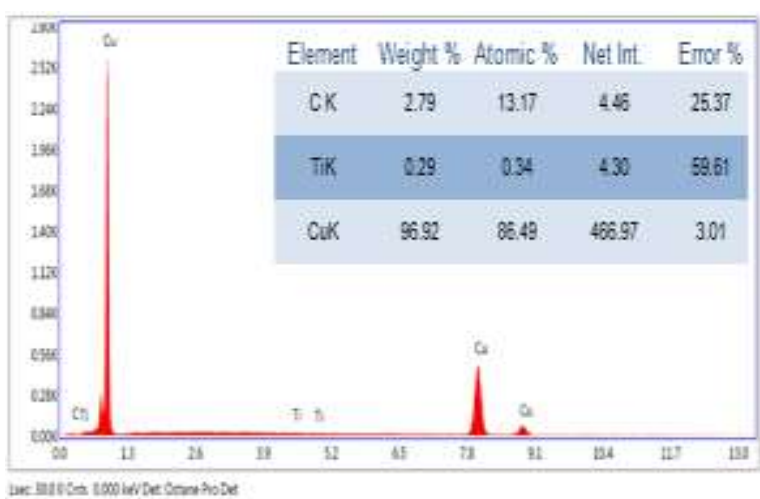

Figure 21.
Result EDS Area 1 


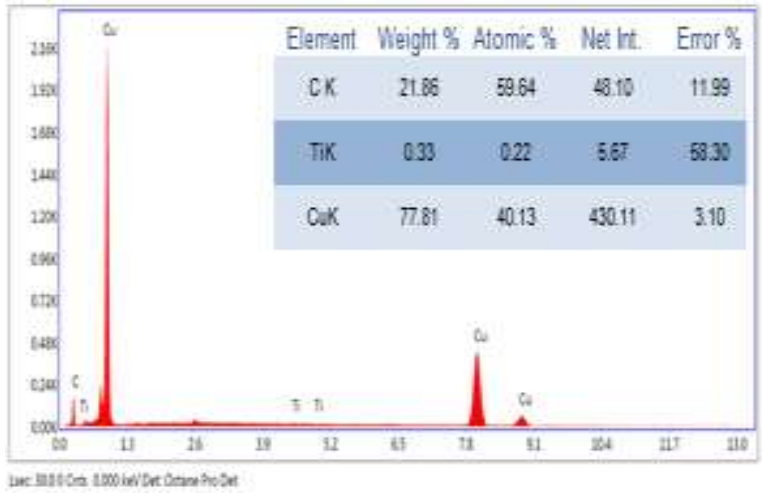

Figure 22.

Result EDS Area 2

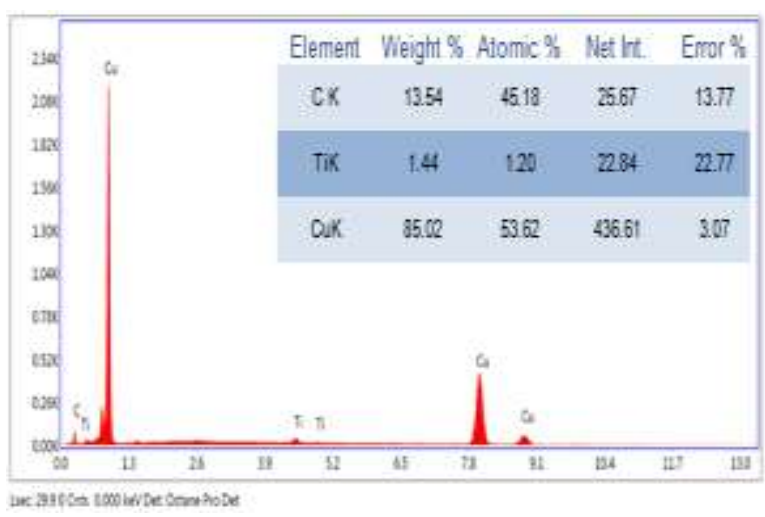

Figure 23.

Result EDS Area 3

Based on XRD and EDS test results the composition is relatively the same even though the spot and test area differ according to the XRD table in Table 5 and Table 6 , and Figure 15 and Figure 16 where the highest element is $\mathrm{Cu}$ as the main element then $\mathrm{Ti}$ and C which form graphite as well as the EDS test which shows the element $\mathrm{Cu}$ as the element with the highest percentage then $\mathrm{Ti}$ and $\mathrm{C}$ as the reinforcing element ${ }^{11}$.

\section{CONCLUSIONS}

From the results of this study, it can be concluded that the addition of $\mathrm{Ti}$ can affect the mechanical properties of the material, one of which is hardness. The highest hardness value is owned by samples with $\mathrm{Ti} 1.5 \%$ at $800^{\circ} \mathrm{C}$, which is $87.25 \mathrm{HVN}$ and the lowest hardness is owned by samples with $\mathrm{Ti} 0 \%$ at $1,000^{\circ} \mathrm{C}$ temperature which is $28.18 \mathrm{HVN}$.

The temperature variation influence on the grain size of the material after measuring grain size, the higher the temperature given, the larger the grain size is in line with the decreasing value of the material hardness. After doing a qualitative analysis on the sample, it can identify the phases that appear, items with a bright colour $(\mathrm{Cu})$, black with a position on the grain boundary (Carbon), and grains with a grey colour (Ti). Based on the results of the calculation of average grain size with the Heyn method, the largest average grain size is $3.25 \mu \mathrm{m}$ in the Ti sample of $0 \%\left(1,000^{\circ} \mathrm{C}\right)$ and the smallest average size of the meat is 2.00 $\mu \mathrm{m}$ in the Ni sample of $1.5 \%\left(800^{\circ} \mathrm{C}\right)$. Likewise, with the results of the Jeffries method which is directly proportional to the Heyn even though the nominal yields are different. Temperature variation also affects the percentage of porosity of the material, the higher the temperature given, the percentage of porosity decreases due to the greater necking area of each powder particle. The lowest porosity value is owned by a temperature of $1000^{\circ} \mathrm{C}$, with $\mathrm{Ti} 1.5 \%$ of 2.491 . While the highest porosity $\%$ value is at a temperature of $800^{\circ} \mathrm{C}$ with Ti $0 \%$ of $10.279 \%$.

\section{ACKNOWLEDGEMENTS}

The author thanks the Center for Applied Nuclear Science and Technology (PSTSNT) National Nuclear Power Agency (BATAN) for providing funds and facilities to carry out this research. As well as to Devi Eka Septiyani Arifin, S.Sc., MS, for their discussions and guidance throughout the research process.Main contributor Andhika AR and Pawawoi.

\section{REFERENCES}

1. Liu, Z., Numerical Study on Multipantograph Railway Operations at High Speed, Thesis in Vehicle and Maritime Engineering, KTH Royal Institute of Technology, Sweden, 2015.

2. Deng, C., Yin, J., Zhang, H., Xiong, X., Wang, P., and Sun, M., The Tribological Properties of $\mathrm{Cf} / \mathrm{Cu} / \mathrm{C}$ Composites Under Applied Electric Current, Tribol. Int., Vol. 116, December 2017, p.84-94.

3. Fadhila, M.N., Jakarta's Commuter Line Train Gets Ready for More Passengers in 2018,

https://republika.co.id/berita/nasional/jabo detabek-nasional/18/01/04/p20z6k383operator-krl-commuter. Accessed in November 2020.

4. Arnold, M., and Simeon, B., Pantograph and Catenary Dynamics: A Benchmark Problem and its Numerical Solution, Appl. Numer. Math., Vol. 34, No. 4, 2000, p. 345-362.

5. Wu, G., Wei, W., Gao, G., Wu, J., and Zhou, Y., Evolution of the Electrical Contact of Dynamic Pantograph- 
Catenary System, J. Mod. Transp., Vol. 24, No. 2, 2016, p.132-138.

6. Cohen, M., Addison-Wesley Metallurgy Series, Addison-Wesley Publishing Company, Inc., Massachusetts, 1956.

7. Girão, A.V., Caputo, G., and Ferro, M.C., Application of Scanning Electron Microscopy-Energy Dispersive X-Ray Spectroscopy (SEM-EDS), Compr. Anal. Chem., Vol. 75, 2017, p.153-168.

8. Dieter, G.E., Mechanical Metallurgy: by George E. Dieter, Jr. 615 pages, diagrams, illustrations, $6 \times 9$ in. New York, McGraw-Hill Book Co., Inc., 1961. Price, $\$ 12.50$, Journal of the Franklin Institute, Vol. 273, No. 4, 1962, p.338.

9. Ruwaida, A.F., Widyastuti, and Rochiem, R., Sintesis MMCs Cu-Al2O3 Melalui Proses Metalurgi Serbuk dengan Variasi Fraksi Volum Al2O3 dan Temperatur Sintering, https://adoc.tips/al-2-o-3melalui-proses-metalurgi-serbuk-denganvariasi-frak.html. Accessed on March 2020.

10. Davis, J.R., and Associates, ASM Specialty Handbook: Copper and Copper Alloys, ASM International, Materials Park, OH 44073-0002, USA, 2001.
11. Ngai, T.L., Zheng, W., and Li, Y., Effect of Sintering Temperature on the Preparation of Cu-Ti3SiC2 Metal Matrix Composite, Prog. Nat. Sci. Mater. Int., Vol. 23, No. 1, 2013, p.70-76.

12. ASTM E112-10, Standard Test Methods for Determining Average Grain Size, ASTM International, West Conshohocken, PA, 2010, www.astm.org.

13. Mataram, A., and Rochardjo, H.S.B., MAT/19-31P Physical and Mechanical Properties of Composite Copper/Carbon, Proceeding of ICCS 2007, YogyakartaIndonesia, 24-25 May 2007.

14. Upadhyaya, G.S., Powder Metallurgy Technology, Cambridge International Science Publishing, England, 2002.

15. Lubis, K., Metoda-Metoda Karakterisasi Nanopartikel Perak, Jurnal Pengabdian Kepada Masyarakat., Vol. 21, No. 79, 2015, p.50-55. 
(halaman ini sengaja dikosongkan) 